British Journal of Education

Vol.8, Issue 1, pp.45-54, January 2020

Published by ECRTD- UK

Print ISSN: ISSN 2054-6351 (print), Online ISSN: ISSN 2054-636X (online)

\title{
EFFECTS OF GUIDED INQUIRY AND INDIVIDUALIZED STRATEGIES ON THE ACADEMIC PERFORMANCE OF SENIOR SECONDARY SCHOOL ECONOMICS STUDENTS IN IMO STATE
}

\author{
Aguguam Chigozi N. \\ University of Port Harcourt \\ Dr. Okoro Cecilla O. \\ University of Port Harcourt
}

\begin{abstract}
This study examined the effect of guided inquiry and individualized strategies on the academic performance of senior secondary school economics students in Imo State. The study was carried out using quasi-experimental, non-randomized control group pretest posttest design, having two aims of the study, two research questions and hypotheses. A total of one hundred (100) senior secondary school two students (SSII) were drawn from two co-educational schools and two intact classes constituted the same size for the study. The schools were selected by purposive sampling likewise the intact classes, the researchers classified the students into 50 students per group (that is treatment group) fifty (50) while control group fifty (50). One instrument was used for collecting the data of the study. The instrument was: Economics Achievement Test (EAT). Research questions were answered using mean and standard deviation while analysis of covariance (ANCOVA) was used to test the hypotheses at 0.05 level of significance. The major finding was that male students performed better than the female students taught Economics with individualized teaching strategy and guided inquiry strategy respectively. Based on the findings of this study, it was recommended that individualized teaching strategy should be encouraged by teachers in the teaching of Economics to enhance the quality of performance in the subject.
\end{abstract}

KEYWORDS: individual learning strategy, guided inquiry strategy, academic performance.

\section{INTRODUCTION}

Economics is one of the subjects taught in senior secondary schools and it takes a central position in student learning, as approved by the Federal Republic of Nigeria. in her National Policy on Education (2013). The Comparative Education Study and Adaptation Centre (CESAC) developed the document in 1985 and later reviewed by the Nigerian Education Resource Development Centre (NERDC). The curriculum is built on the principle of providing Senior Secondary School graduates with basic understanding and abilities to appreciate the economic problems of what to produce, how to produce and find out ways of solving them in the Nigerian Economy. Its structure and theme design follows a spiral form from Senior Secondary (SS1-SSIII); simple to complex with in-built teachers and learners activities for each topic. This is because it occupies a central position in student learning as one of the subjects taught at the upper basic level of education and very vital in every aspect of life. In spite of the central position occupied by Economics as an 
elective secondary school subject. It is still difficult to give a precise and generally acceptable definition of Economics. This is because several Economists have given several definitions. Most of what one does every day come under the subject matter of Economics. Thus, in Nigeria, people are performing many kinds of activities in order to satisfy their basic need like food, shelter and clothing and other aspects of human needs. Almost all business transactions involve many branches of the subject. Farmers produce yams and exchange them for money; while lawyers give legal advice to clients in exchange for money, firms like Lever Brothers. Paterson Zochonis (P.Z) and Dangote produce goods such as detergents, cement, and flour respectively, while banks provide loans.

Anyanwuocha (2013) gave a precise definition of Economics as the science which studies the behaviour of humans as it relates to ends and scarce means which have alternative uses. Economics as a senior secondary school subject relates directly to the administration of scarce resources in human society. Njoku (2008) relates Economics to human beings who live within a framework of a given historical civilization as it relates to their experience in various wants, such as food, shelter, clothing, education, social prestige, entertainment, expression of religious beliefs and so on in relation to the scarce resources to satisfy human wants. Economics as a secondary school subject has relevance virtually in all human activities and the economy. Economics as a secondary school subject is a broad field knowledge that is concerned with economic and social relations of human life. It is science supported by many disciplines or areas which among others are Micro Economics, Applied Economics, and Monetary Economics and so on. Economics as a subject is accorded recognition of a viable course towards national development. Thus, the emphasis is on science and technology which have brought the awareness that Economics solves Socio-economic and political problems in the modern society. Adeyemi (2002) notes that the inclusion of Economics in senior secondary curriculum is to help students decide the alternative uses of scarce resources and to satisfy their numerous needs.

For Marshal (2001:40), economics is the study of mankind in the ordinary business of life. It examines that part of the individual and social action which is most closely connected with the attainment and with the use of the material requisites of well-being. Economics thus, contributes meaningfully to the intellectual development of students. The central objectives of teaching Economics are in line with the central purpose of education. The Federal Republic of Nigeria (FRN, 2013:4) outlined the cardinal national objectives as the building of: a free and democratic society, a just and egalitarian society, a united, strong and self-reliant nation, a great and dynamic economy, and a land full of opportunities for all citizens. This is achievable through the effective implementation of the objectives of Economics curriculum in senior secondary schools. The Economics curriculum is basically designed to promote objectivity and independent thinking. It makes students to think and behave objectively in contrast to subjective ways. It makes students not to accept statements without verification. The importance of Economics as a secondary school subject cannot be over emphasized and its introduction in secondary schools since mid-sixties cannot be undermined. According to NERDC (2008), the objectives of teaching Economics in senior secondary schools are to enable students: 
British Journal of Education

Vol.8, Issue 1, pp.45-54, January 2020

Published by ECRTD- UK

Print ISSN: ISSN 2054-6351 (print), Online ISSN: ISSN 2054-636X (online)

1. Understand basic Economic principles and concepts as well as the tools for sound Economic analysis.

2. Contribute intelligently to discourse on Economic reforms and development as they affect or would affect the generality of Nigerians.

3. Understand the structure and functioning of Economic institutions.

4. Appreciate the role of public policies on national economy.

5. Develop the skills and also appreciate the bases for rational economic decisions.

6. Become sensitized to participate actively in national Economic advancement through entrepreneurship.

7. Understand the role and status of Nigeria and other African countries in international economic relationships.

8. Appreciate the problems encountered by developing countries in their effort towards economic advancement.

Economics, as a subject and discipline prepares the students to be active and functional. Despite these great ideas and importance being accorded to economics, there tends to be a growing concern among economists, and other educators on how best to teach economics in senior secondary schools for greater performance. Researchers have shown that economics need to be taught with innovative methods that can allow the learner to participate and contribute meaningfully to the society (Osakwe \& Oganwu, 2005). The strategy that a teacher uses has potential of promoting, hindering learning, sharpening mental activities, encouraging initiative and curiosity and thus making for self-reliance and survival. UNESCO in Obih (2012) sees strategy as a particular procedure or procedure used to structure teaching and learning situations.

\section{Guided Inquiry Strategy}

Guided inquiry is a student-centered strategy of teaching whereby students interact actively. Question assumptions and provide their viewpoints on any area of subject matter. (Olibie and Ezeoba, 2013). It is done through investigations at the students' own rates and levels of ability which makes learning to take place.

Guided inquiry emphasizes higher-level thinking skills and collecting, analyzing and synthesizing information and data from multiple sources and viewpoints. Wilson, Taylor, Kowalski and Carison (2010) averred that the teacher uses this strategy to present concrete experiences of authentic problems and the research materials that students would examine in order to reach a conclusion about the problem. Also, the teacher asks lots of questions and uses speculative statements with many speculative interactions designed to raise issues for students' discussion. Students are allowed to probe public issues based on instructional content.

The Education Endowment Foundation (2017) opined that individualized strategy involves pro ding different tasks for each learner and support at the individual level. It is based on the idea that all learners are different and have different needs, and that therefore a personally tailored approachparticularly in terms of the tasks and activities that pupils undertake and the pace at which they make progress through the curriculum-will be more effective. Also, Knowledge Network for Innovations in Learning and Teaching (2016) affirmed that individualized strategy is a radical 
departure from conventional instruction strategies because it allows students to proceed through a body of material at their own pace, instead of a pace that is pre-determined by the teacher. Much of the content for individualized learning strategy comes through prepared materials that students study for each unit. It means that in individualized earning strategy learning environment, the role of the teacher changes significantly. According to Anugom (2015) academic performance refers to how students deal with their studies and how they cope with or accomplish different tasks given to them by the teachers.

\section{Gender Influence on Students' Academic Performance}

Gender is linked to social behaviours which are deemed to be appropriate to masculine and feminine roles in the society. It separates women roles and responsibilities in relation to those of the men. Gender is associated with the belief, attitude and societal perception of being a male or female vis-ã-vis what each should do, how each should behave, and social functions as well as position they can attain in the society (Obib, 2017). Sunday (2007) defines gender as a socially or culturally constructed characteristics, roles and qualities which different societies ascribe to males and females varying from one society to another and at different times in history. Gender is therefore seen as the allocation of roles based on sex in a given society. Gender stereotypism is fixing roles as a result of bias resulting from socio-cultural orientations over the years. These stereotypes affect ones sense of self-worth, behaviour and choices. It has permeated into the home, the school, politics, economics, and religion and all spheres of life. There is presently gender confusion in students' attitude towards economics. It has come to notice that boys are more inclined to the Mathematical aspect of the subject while girls are more interested to sit in class and listen to lectures on economics.

\section{Statement of the Problem}

Notwithstanding the lofty ideas and the seemingly great importance being accorded to Economics, a growing concern exists among Economists and other Educators on how best to teach Economics in senior secondary schools for better results. The weaknesses of students and poor academic performance shows a disconnect between the objective and philosophy of teaching Economics and this was evidenced in the West African Examination Council (WAEC) Chief Examiners Reports, 2009, 2010, 2011, 2012 and 2013 which have constantly drawn attention of all especially in Owerri Municipal Local Government Area of Imo state. The reports revealed the following weaknesses: shallow coverage of the syllabus, inability to draw and label diagrams properly and disobedience to the rubrics. One wonders if the mass failure of students in Economics could be linked to the strategy/strategies which the teacher uses in his/her classroom. Would Economies be taught with innovative strategies that could allow meaningful learner participation and contribution to the society? This formed the bedrock for this study.

\section{Objectives}

The aim of this study is to investigate the relative effectiveness of guided inquiry and individualized strategies on the academic performance of senior secondary school Economics students' in Imo State.

Specifically, the study sought to; 
British Journal of Education

Vol.8, Issue 1, pp.45-54, January 2020

Published by ECRTD- UK

Print ISSN: ISSN 2054-6351 (print), Online ISSN: ISSN 2054-636X (online)

1. Determine the difference in the mean scores of Economics students' in the individualized and guided inquiry learning groups.

2. Examine the effects of individualized and guided inquiry teaching strategies on the mean performance of male and female students' in Economics.

\section{Research Questions}

The following research questions were answered to arrive at the findings of the study.

1. What differences exist in the mean scores of students in the individualized and guided inquiry groups?

2. Are there effects of individualized and guided inquiry teaching strategies on the performance of male and female students' in Economics?

\section{Hypotheses}

The following null hypotheses were formulated and tested at 0.05 level of significance to guide this study:

1. There is no significant difference in the mean scores of students in the Individualized and Guided Inquiry groups.

2. There is no significant difference on the mean performance of male and female students in Economics using individualized and guided inquiry teaching strategies.

\section{METHODOLOGY}

This study used quasi--experimental non-randomized control pretest-posttest design, which is partly true experimental design, however, it does not employ randomization procedure during assignment of subjects to groups. The study has three (2) groups (one control group and one experimental group) that were pretested to examine equality in variance. The population consisted of all public secondary schools (SS2) in Owerri Municipal of Imo state. Sample of 100 students were selected using simple random and purposive sampling technique.

\section{Instrument for Data Collection}

The instrument that was used for the collection of data for this study is Economics Performance Test (EPT). The Economics Performance Test was used to elicit response on the performance of students in Economics. The test items were derived from the four different topics (population. labour market. distributive trade and money) for which the lesson plans were prepared within economics content. The testwere made up of twenty (20) items of multiple choice questions with four options. Lettered A to D, each of which only one of the options, is the correct answer.

\section{Administration of the Instrument}

A total of twenty Economics Performance Test (EPT) copies were administered to economics students of the sampled schools. Twenty copies were administered to experimental groups (guided inquiry and individualized learning strategy group) and twenty copies to control group. All the copies of the Economics Performance Test (EPT) were received and analyzed. Data were analyzed using mean and standard deviation and ANCOVA. 
British Journal of Education

Vol.8, Issue 1, pp.45-54, January 2020

Published by ECRTD- UK

Print ISSN: ISSN 2054-6351 (print), Online ISSN: ISSN 2054-636X (online)

\section{RESULTS}

The results of the study were obtained from the research questions hypotheses answered through data collected and analyzed.

\section{Research Question 1}

What differences exist in the mean scores of students in the Individualized and Guided Inquiry groups?

Table 1: Mean performance scores of students in the mean scores of students in the Individualized and guided inquiry groups

\begin{tabular}{|c|c|c|c|c|c|c|}
\hline \multirow[t]{2}{*}{ Group } & \multirow[t]{2}{*}{$\mathbf{n}$} & \multicolumn{2}{|c|}{ Pre-test } & \multicolumn{2}{|c|}{ Post-test } & \multirow[t]{2}{*}{ Gained mean } \\
\hline & & Mean & SD & Mean & SD & \\
\hline Individualized Teaching Strategy & 50 & 7.00 & 1.81 & 15.32 & 2.52 & 8.32 \\
\hline Guided Inquiry Strategy & 50 & 7.12 & 1.86 & 11.36 & 91.82 & 4.24 \\
\hline
\end{tabular}

The result presented in Table 1 shows that students taught Economics with individualized teaching strategy had pre-test performance mean score of 7.00, post-test mean score of 15.32 and mean performance gain score of 8.32 while those students that were taught Economics with guided inquiry strategy had pre-test achievement mean score of 7.12, post-test mean score of 11.36 and mean performance gain score of 8,32 .

\section{Research Question 2}

Are there effects of individualized and guided inquiry teaching strategies on the performance of male and female students' in Economics?

Table 2: Mean performance scores of male and female students taught Individualized and those taught economics using guided inquiry strategies economics

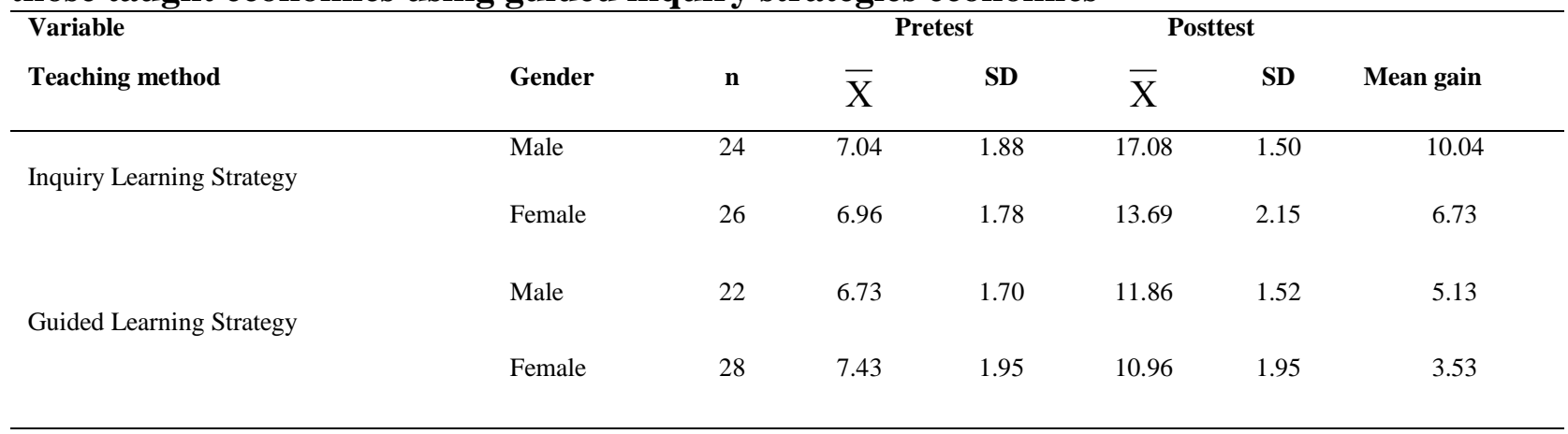

The result presented in Table 4 above showed the effects of individualized and guided inquiry teaching strategies on the performance of male and female students' in Economics. The result 
Vol.8, Issue 1, pp.45-54, January 2020

Published by ECRTD- UK

Print ISSN: ISSN 2054-6351 (print), Online ISSN: ISSN 2054-636X (online)

shoed that male and female students taught Economics with individualized teaching strategy had post-test mean performance scores of 17.08 and 13.69 respectively. On the other hand, the male and female students taught Economics with guided inquiry strategy had a post-test mean score of 11.86 and 10.96 respectively.

\section{Testing Hypotheses}

HO1: There is no significant difference in the mean scores of students in the Individualized and Guided Inquiry groups.

Table 3: Summary of ANCOVA of students' performance based on methods

\begin{tabular}{|c|c|c|c|c|c|c|}
\hline Source & $\begin{array}{l}\text { Type III Sum of } \\
\text { Squares }\end{array}$ & df & Mean Square & $\mathbf{F}$ & $P$ & Sig \\
\hline Corrected Model & $396.388^{\mathrm{a}}$ & 2 & 198.194 & 41.074 & .000 & $\mathrm{P}<0.05$ \\
\hline Intercept & 972.712 & 1 & 972.712 & 201.587 & .000 & $\mathrm{P}<0.05$ \\
\hline Pretest & 4.348 & 1 & 4.348 & 901 & .345 & $\mathrm{P}>0.05$ \\
\hline Treatment & 394.344 & 1 & 394.344 & 81.725 & .000 & $\mathrm{P}<0.05$ \\
\hline Error & 468.052 & 97 & 4.825 & & & \\
\hline Total & 18660.000 & 100 & & & & \\
\hline Corrected Total & 864.440 & 99 & & & & \\
\hline
\end{tabular}

Table 3 revealed summary of analysis of covariance of students' performance based on the two methods, using pretest scores as a covariate, $\mathrm{F}_{1.97}=81.725$ with $\mathrm{P}=.000, \mathrm{P}<0.05$.

HO2: There is no significant difference on the mean performance of male and female students in Economics using individualized and guided inquiry teaching strategies.

Table 4: Summary of ANCOVA of students' performance based on gender

\begin{tabular}{|c|c|c|c|c|c|c|}
\hline Source & $\begin{array}{l}\text { Type III Sum of } \\
\text { Squares }\end{array}$ & df & Mean Square & $\mathbf{F}$ & $P$ & Sig \\
\hline Corrected Model & $551.029^{\mathrm{a}}$ & 4 & 137.757 & 41.756 & .000 & $\mathrm{P}<0.05$ \\
\hline Intercept & 953.092 & 1 & 953.092 & 288.898 & .000 & $\mathrm{P}<0.05$ \\
\hline Pretest & 5.516 & 1 & 5.516 & 1.672 & .199 & $\mathrm{P}>0.05$ \\
\hline Treatment & 393.406 & 1 & 393.406 & 119.248 & .000 & $\mathrm{P}<0.05$ \\
\hline Gender & 117.608 & 1 & 117.608 & 35.649 & .000 & $\mathrm{P}<0.05$ \\
\hline Treatment*Gender & 34.991 & 1 & 34.991 & 10.606 & .002 & $\mathrm{P}<0.05$ \\
\hline Error & 313.411 & 95 & 3.299 & & & \\
\hline Total & 18660.000 & 100 & & & & \\
\hline Corrected Total & 864.440 & 99 & & & & \\
\hline
\end{tabular}

Table 4 revealed summary of analysis of covariance of students' performance based on the gender, using pretest scores as a covariate, $\mathrm{F}_{1.97}=35.649$ with $\mathrm{P}=.002, \mathrm{P}<0.05$. 
Vol.8, Issue 1, pp.45-54, January 2020

Published by ECRTD- UK

Print ISSN: ISSN 2054-6351 (print), Online ISSN: ISSN 2054-636X (online)

\section{DISCUSSION OF RESULTS}

The result presented in Table I shows that students taught Economics with individualized teaching strategy had pre-test performance mean score of 7.00, post-test mean score of 15.32 and mean performance gain score of 8.32 while those students that were taught Economics with guided inquiry strategy had pre-test achievement mean score of 7.12. post-test mean score of 11.36 and mean performance gain score of 8.32. This result indicates that individualized teaching strategy is more effective and improves students' academic performance in Economics more than the guided inquiry strategy.

The result presented in Table 2 above showed the effects of individualized and guided inquiry teaching strategies on the performance of male and female students' in Economics. The result showed that male and female students taught Economics with individualized teaching strategy had post-test mean performance scores of 17.08 and 13.69 respectively. On the other hand, the male and female students taught Economics with guided inquiry strategy had a post-test mean score of 11.86 and 10.96 respectively. This result indicated that the male students had higher mean scores than the female. That is to say that the male students performed better than the female students taught Economics with individualized teaching strategy and guided inquiry strategy respectively. Table 3 shows the Analysis of Covariance (ANCOVA) for test of Hypothesis 3. The F-calculated (F- cal) value of 81.725 and the p-value of 0.000 which is less than 0.05 level of significance. indicating that there was significant difference in the mean scores of students in the Individualized and Guided Inquiry groups. Therefore, the null hypothesis of no significant difference in the mean scores of students in the Individualized and Guided Inquiry groups was rejected.

Table 4 shows the Analysis of Covariance (ANCOVA) for test of Hypothesis 4. The F-calculated (F- cal) value of 35.649 and the p-value of 0.000 which is less than 0.05 level of significance. indicating that there was significant difference on the mean performance of male and female students' in Economics using individualized and guided inquiry teaching strategies. Therefore, the null hypothesis of no significant difference on the mean performance of male and female students' in Economics using individualized and guided inquiry teaching strategies was rejected

\section{Recommendations}

Awotua-Efebo (2007) and Urenyere (2013) gave the following recommendations as thus:

1. Efficient use of Individualized strategy: Awotua-Efebo (2007) indicated that individualized learning gives students flexible choices in objectives of learning, rate of learning, method (style) of learning, and content of learning; because it improves students' level of awareness of metacognition as they apply the skills to problem solving in more direct content specific was.

2. Effective use of Guided Inquiry strategy: inquiry method improves performance scores and interest of high and low ability students than the lecture method. Similarly. Urenyere (2013) indicated that there is a significant difference in performance of participant with the adoption of enter educate, guided disc3very and value clarification teaching skills vis- a -vis the conventional method. 
3. Gender raises the issue of sets of relationships, attributes, roles, beliefs, and attitudes that define what being a man or a woman is within the society. The teacher should motivate students and ensure that they choose activities suitable for the achievement of mastery and maximum efficiency.

4. Enlightenment campaign, workshops and seminars should be organized for teachers by Education Authorities-Federal and State Ministries of Education, institutes and Colleges of Education to create awareness of the efficacy of the strategies/methods and then sensitize the adoption of the methods/strategies in their various schools.

5. Individualized teaching strategy should be incorporated into teacher education curriculum and be taught as other teaching methods since it is a relatively new technique with many stages for its successful implementation

\section{CONCLUSION}

Guided inquiry and individualized teaching strategies are effective in improving students' academic performance in economics. This means that students taught with guided inquiry and individualized strategies achieved higher mean academic achievement scores than those taught with lecture method. Therefore, guided inquiry approach and individualized strategies are effective in improving students' academic performance.

\section{References}

Adeyemi, T.O. (2006). Predicting students' performance in the senior secondary certificate examination from the performance of junior secondary certificate examination in Ondo State. African Journal of Educational Studies, 4(1), 41-61.

Anugom. F.O. (2015). Gender equity and roles in the sustainability of secondary school administration in Nigeria. International Journal of Gender and Development Issues. 1(4) $1-7$.

Anyanwuocha, RA.. (2013). Fundamentals of economics (3rd edition). Onitsha: Africana tirst publishers plc.

Awotua-Efebo. E.B. (2007). Effective Teaching: Principles and practice. Port Harcourt: Para graphics

Drayton. k, \& FalL J.K. (2001). Tell-tale signs of the inquiry-oriented classroom. NASSP Bulletin, 85 (623), 24-34

Education Endowment Foundation (2017). Retrieved online 04/07/2017 from https://educatself ionendowmentfoundation.org.uk/resources/teaching-learning-toolkit/individualisedinstruction.

FRN (2013). National Policy on Education, Lagos, Nigeria: NERDC press.

Knowledge Network for Innovations hi Learning and Teaching (2017). Retrieved from http //tco rtabjy eeL..kniftjidex php/Effective Use of Self paceclLgrrnngjjjthe ironment

Marhal, B.K. (2001). Practical methods for teaching of thinking. London: Routledge.

Nigerian Educational Research and Development Council (2008). Senior Secondary Education Curriculum Economics for SSI-3. Abuja: NERDC Press.

Njoku, A (2008). Microeconomics. Owerri: Ozyvic Productions Ltd. 
Vol.8, Issue 1, pp.45-54, January 2020

Published by ECRTD- UK

Print ISSN: ISSN 2054-6351 (print), Online ISSN: ISSN 2054-636X (online)

Obih, S.O.A. (2017). Relative effectiveness of the discovery, cooperative and inquiry reaching methods on student academic achievement in economics in senior secondary schools in mm state. Unpublished Doctoral Thesis, Department of Curriculum and Teacher Education, Faculty of Education. Abia State University. 1Jturu, Nigeria.

Obih. S.O.A. (2012). New perspective in teacher education in the 21 century, what principles? What method? Journal of Faculty of Education. University of Benin: Benin City 10) 3240 . 